\title{
Assessment of the Effect of Different Packaging Materials on Some Quality Indices of a Nigerian Stick Meat (Tsire) during Storage
}

\author{
Olusegun A. Olaoye ${ }^{1 *}$, Stella C. Ubbor ${ }^{1}$ and Iniobong G. Lawrence ${ }^{2}$ \\ ${ }^{1}$ Department of Food Science and Technology, Michael Okpara University of Agriculture, Umudike, Abia State, \\ Nigeria \\ ${ }^{2}$ Department of Food Technology, Federal Polytechnic, Offa, Kwara State, Nigeria \\ Email: olaayosegun@yahoo.com
}

\begin{abstract}
This study examined the effect of different packaging materials on some quality indices of a Nigerian stick meat (tsire) during spontaneous storage at $30^{\circ} \mathrm{C}$ for four days. The packaging materials included those normally used for wrapping of the product during sales to consumers, and they were 'common paper', 'dry banana leaves', 'cellophane paper' and 'aluminium paper'. Analysis during storage showed that the tsire samples stored in cellophane paper had the highest concentration of lactic acid $(14 \mathrm{~g} / \mathrm{kg})$, while $10 \mathrm{~g} / \mathrm{kg}$ was recorded as the lowest concentration for samples stored in common paper. There was reduction in $\mathrm{pH}$ of the tsire samples stored in the different packaging materials during storage from 6.9 on day 1 to 5.9 on day 4, although no significant difference $(\mathrm{p}>0.05)$ was recorded between samples. Thiobarbituric acid (TBA; mg malonaldehyde/ $\mathrm{kg}$ sample) ranged from 0.38 and 040 on day 1 among the different samples, and the values increased during storage to a range of 0.74 to 0.81 on day 4 ; however, the values did not differ significantly $(\mathrm{p}>0.05)$ among samples. Principal component analysis (PCA) of the volatiles associated with the tsire samples during storage indicated that known spoilage compounds, including nonanal and heptanal, were detected in all samples, especially on days 3 and 4 . In conclusion, the different packaging materials recorded no significant effect $(\mathrm{p}>0.05)$ on the tsire samples during storage. However, TBA values and volatiles recorded suggested likely presence of spoilage in the samples during storage.
\end{abstract}

Keywords: Spontaneous storage; quality indices; tsire; packaging materials; thiobarbituric acid; spoilage compounds.

\section{Introduction}

Tsire is a roasted, boneless meat of either beef, goat, or mutton that is cooked around a glowing charcoal fire in which the meat pieces are staked on wood sticks, spiced with peanut cake, spices, vegetable oil, salt or other flavourings [1]. It is a delicatessen item since it does not receive any treatments designed to extend its shelf life. As a matter of fact, most sales-points hardly exhaust their sales and such leftovers are often carried over to the second or other days. This may bring about development of rancidity, causing spoilage of the meat product. Proper storage of meat and meat products is thus an important means of increasing shelf life and preventing or limiting microbial contamination.

Packaging materials are known as possible source of microbial contamination of food. Since food eaten has a direct influence on health, it is therefore important that manufacturer and food handlers keep food safe, especially from harmful hazards. Cellophane is the largest volume of single film used in flexible packaging industry [2], and is a low cost film with moderate tensile strength and clarity, and is a good moisture barrier. Local packaging alternatives include leaves of plants such as banana, cocoa, and cocoyam, which are large caudate leaf borne on petioles of different wideness. These plants occur wide in the African rain forest, large, cheap, and readily available and provide good packaging for products that are quickly consumed. They are common in the lowland tropics of Africa, Central Latin America, Southeast Asia, and West Indies. 
Kabuo et al. [3] reported the effect of wrapping materials on the proximate composition and organoleptic properties of Usu (indigenous meat analogue) produced from big mushroom (lentinus tuberregium) and melon seed. The packaging material used by the authors were Christmas bush leaves (CBL), Asusu leave (AS), African boundary leaves (ABL), Miraculous fruit leaves (MFL) and Aluminum foil; it was concluded that significant difference occurred in some of the quality attributes evaluated by the authors in the meat analogue. In another study, Ogunsola and Omojola [4] also evaluated the effect of packaging materials including polyvinyl chloride, aluminium foil and plastic container on the quality attributes of Kilishi, a dry intermediate moisture Nigerian meat product prepared from beef and pork. The authors noted significant effect in some of the quality attributes as impacted by the packaging materials. Packaging is one area that has attracted attention because the use of suitable materials for food products may improve their shelf life and contribute to wholesomeness. Due to the growing number of urban dwellers who are becoming increasingly dependent on grilled meat products sold along streets, it is important to examine the type of packaging materials used by sellers of tsire and other grilled meat products as well as their effect on the quality characteristics of the products.

In Nigeria and many West African countries, producers of tsire don't normally exhaust their sales on the day of production, and leftovers are usually stored in different packaging materials until they are sold out; and this may take few days [5]. The packaging materials may therefore have some level of influence on the chemical and volatile qualities of the product, which may invariably affect its shelf life. The present study therefore examined the use of different packaging materials on selected quality parameters of tsire during spontaneous storage at ambient temperature. Results of this finding may be useful towards advising sellers of the product on the best packaging material during storage of the product, especially in protecting consumer's preference for quality.

\section{$2 \quad$ Materials and Methods}

\subsection{The Meat and Ingredients Used}

The meat used in this study was purchased from a butcher's shop in the city of Nottingham, UK, and conveyed to the laboratory over ice crystals for processing. The ingredients used included ground red pepper (Capsicum sp.), onions (Alium cepa), ginger (Zingiber officinalis), groundnut (Arachis hypogaea) and salt, obtained from a Nigerian shop in the same city.

\subsection{Preparation and Storage of Stick Meat - Tsire}

The stick meat (tsire) samples were prepared according to the method described by Olaoye [6]. The stick meat samples were kept inside common paper, dry banana leaves, cellophane paper, and aluminium foils separately and stored for four days in a storage cabinet at $30^{\circ} \mathrm{C}$ (representing approximate ambient temperature in Nigeria), during which period samples were taken in replicates for analysis.

\subsection{Measurement of Organic Acids in the Stick Meat during Storage}

Measurement of organic acids (lactic and acetic acids) in the stick meat (tsire) samples stored in different packaging materials were carried out using the HPLC method described by Olaoye et al. [7]. Concentrations of the organic acids were expressed in $\mathrm{g} / \mathrm{kg}$. The HPLC system used consisted of LC10ADVP pump (Shimadzu, UK), equipped with injection valve of $20 \mu$ l capacity; UV detector (SpectroMonitor 3000, LDC/Milton Roy, Florida, USA); Data recorder (Picolog for windows, Release 5.12.1, St Neots, UK); C18 analytical column (a reverse phase Techsphere ODS-2 5U,250mm length, $4.6 \mathrm{~mm}$ internal diameter).

\subsection{Measurement of $\mathrm{pH}$ in the Stick Meat during Storage}

The stick meat samples (10 g each) were homogenized in standard stomacher bags (BA 6141, Seward, UK) containing $100 \mathrm{ml}$ sterile deionised water ( $\mathrm{pH}$ 6.8 \pm 0.15 ), using a Seward Stomacher (Model 400 
circulator, $\mathrm{P} / 4 / 518$, Leighton Buzzard, $\mathrm{UK}$ ). $\mathrm{pH}$ was recorded in a $\mathrm{pH}$ meter ( $\mathrm{pH} 212$ Microprocessor, Hanna Instruments, USA).

\subsection{Measurement of Thiobarbituric Acid in the Stick Meat during Storage}

Thiobarbituric acid (TBA) values in the stick meat product were determined by the modified method of Olaoye and Onilude [8]. A portion of comminuted samples $(10 \mathrm{~g})$ was blended with $15 \mathrm{~mL}$ of cold extracting solution containing $9 \%$ perchloric acid. The resulting slurries were transferred quantitatively to $100 \mathrm{~mL}$ volumetric flasks and made up to $50 \mathrm{~mL}$ each with distilled water. The slurries were filtered through Whatman no. 2 filter paper. Fifty milliliters of each of the filtrates was transferred to test tubes and $5 \mathrm{~mL}$ of $0.02 \mathrm{~N}$ TBA reagent was added into each and mixed thoroughly. The tubes were kept in the dark for $17 \mathrm{~h}$ and the absorbance read at $530 \mathrm{~nm}$ with a spectrophotometer (Spectronic 20, Thermo Fisher, Waltham, USA) against a blank containing DW and TBA solution. Malonaldehyde (MDA) concentrations were calculated from a standard curve using solutions of 1,1,3,3 tetraethoxypropane (TEP). The MDA standard stock solution $(10 \mathrm{mM})$ was prepared by acid hydrolysis of $239 \mathrm{ml}$ TEP (97\%, Fisher Scientific, UK) in $100 \mathrm{ml}$ of $1 \%$ sulphuric acid (Fisher Scientific, UK) for $2 \mathrm{~h}$ at room temperature. This was diluted with DW to $100 \mu \mathrm{M}$ and used as working standard solution, from which appropriate dilutions $(0.1$ to $50 \mathrm{\mu M})$ were further made. The absorbance readings of the MDA standard dilutions were used in constructing calibration curve from which MDA in the samples were quantified, using the equation obtained from the linear regression of the standard curve $\left(\mathrm{R}^{2}=0.993\right)$ as follows: TBA $(\mathrm{mg} \mathrm{MDA} / \mathrm{kg}$ sample $)=[(0.0276 \times \mathrm{A}-0.1672) \times 43 \times 67]$, where $\mathrm{A}$ is the absorbance. The samples and standard solutions used for the calibration were taken through the TBA procedure at the same time. Preparations were made in three replicates and TBA values were expressed as mg MDA/kg sample.

\subsection{Analysis of Volatiles in the Stick Meat Product Using Solid Phase Mass Extraction- Gas Chromatography Mass Spectrometry (SPME-GCMS)}

The stick meat samples were taken daily during storage and chemical volatiles were analyzed using SPME-GCMS according to the method described by Olaoye [9]. This was performed by placing $2 \mathrm{~g}$ of samples in $20 \mathrm{ml}$ headspace vials $(22.5 \mathrm{~mm} \times 75.5 \mathrm{~mm}$, Grace Alltech, UK). The vials were sealed with a magnetic cap (20mm diameter, 5mm centre, PTFE/Silicone Liner; Grace Alltech) using a Crimper (Part no 60045, Alltech Associates Inc., USA) and allowed to equilibrate at room temperature $\left(22^{\circ} \mathrm{C}\right)$ for 30 min before commencement of analysis.

A Stableflex fibre coated with 50/30 $\mu \mathrm{m}$ divinylbenzenecarboxen on polydimethylsiloxane bonded to a flexible fused silica core (Supelco, Bellefonte, PA, 16823-0048 USA) was used for the extraction of the flavour volatiles in the headspace of the vials. An extraction time of $15 \mathrm{~min}$ at room temperature was used, while desorption time was set to 4 min at $230^{\circ} \mathrm{C}$.

GCMS was carried out using a Trace GC Ultra gas chromatograph (Thermo Electron Corporation, UK) and a DSQ mass spectrometer (1.4.1 SP3 Thermo Electron Corporation, USA). Samples were injected in splitless mode into the GC with a PAL auto-sampler. Chromatography was carried out with a TRACE GC 2000 series gas chromatograph using a ZB-WAX capillary column (Serial no 162147, Order no 7HG-G007-22, L 30m x I.D. 0.25mm x df 1 $\mathrm{mm}$, USA). Helium was employed as the carrier gas, at a constant pressure of $15 \mathrm{psi}$ and splitless time of $1 \mathrm{~min}$. The oven temperature programme was as follows: an initial temperature of $40^{\circ} \mathrm{C}$ was maintained for $1 \mathrm{~min}$, with ramps $8^{\circ} \mathrm{C} / \mathrm{min}$ to $200^{\circ} \mathrm{C}$ and $10^{\circ} \mathrm{C} / \mathrm{min}$ to a final temperature of $230^{\circ} \mathrm{C}$. Mass spectrometry was performed with a DSQ mass spectrometer. The mass spectrometer was operated in positive ionisation electron impact mode (EI+) at electron energy of $70 \mathrm{eV}$. The scan time was $0.29 \mathrm{~s}$. Samples for injections into the GC were prepared in three replicates. The detector was operated in scan mode, scanning from $\mathrm{m} / \mathrm{z} 20$ to 210 . Source temperature was $200^{\circ} \mathrm{C}$. The data generated were processed with Xcalibur ${ }^{\mathrm{TM}} 1.4 \mathrm{SR} 1$ (Thermo Electron Corporation) software.

The chemical volatile detected in the samples were identified by comparing their mass spectra with those in the National Institute of Standards and Technology (NIST) mass spectral library and/or by calculation of the retention indices relative to a series of n-alkanes (C5-C19; Sigma-Aldrich, UK) and matching them with standard compounds and data reported in the literature $[10,11]$. The results were reported as relative abundance expressed as area units, AUs $\left(\times 10^{4}\right)$. 


\section{7 $\quad$ Statistical Analysis}

Results which depended on different packaging materials and period of storage were analyzed according to a completely randomized design with three replicates. The data obtained were subjected to one way analysis of variance (ANOVA) to evaluate the effect of packaging materials on the samples. Differences between means were evaluated by Duncan's multiple range test and significant difference was expressed at $\mathrm{p}<0.05$. The SPSS statistic programme (version 10.01) was used.

The relationship between the packaging materials and their volatile compounds was evaluated by principal component analysis (PCA) using Xlstat software (ver. 17.3.01.19703; Addinsoft, NY).

\section{$3 \quad$ Results and Discussion}

The result of the organic acid concentration of the tsire samples stored in different packaging materials is presented in Figure 1 after $24 \mathrm{~h}$ of storage; four different packaging materials, normally adopted by producers in the post-production storage of tsire, which included common paper, dry banana leaves, cellophane paper, and aluminium foils, were used in wrapping the product prior to storage. Result indicated that samples stored in cellophane paper recorded the highest lactic acid concentration of 14.0 $\mathrm{g} / \mathrm{kg}$, while the lowest value $(10 \mathrm{~g} / \mathrm{kg})$ was obtained for the sample stored in common paper. The highest concentration of $9.5 \mathrm{~g} / \mathrm{kg}$ was observed for the sample stored in common paper in term of acetic acid while those stored in aluminium paper had the lowest $(7 \mathrm{~g} / \mathrm{kg})$.

It thus appears that cellophane provided a good enabling environment for production of lactic acid in the meat product (tsire), and this may help in promoting shelf life of the product, as a result of contribution of lactic acid towards combating spoilage organisms in meat products [11,12]; cellophane paper may therefore be a good packaging material for tsire during short period of storage by producers. On the other hand, common paper having the highest production of acetic acid may not be suitable as packaging material for tsire, as a result of undesirable effect that acetic acid is known to impart on sensory quality of meat; acetic acid has been reported to cause unpleasant taste to food products, especially meat, unlike lactic acid [13].

Measurement of $\mathrm{pH}$ in the tsire samples during storage (Figure 2) indicates that decrease in values was recorded with progression in the storage period. The trend seems to contrast the pattern recorded for the organic acids (i.e. lactic and acetic acids), suggesting an inverse correlation between concentration of organic acids and $\mathrm{pH}$ values of the tsire samples. In a research investigation on the use of biological agents in the extension of fresh been in Nigeria, Olaoye and Onilude [8] attributed the reduction in $\mathrm{pH}$ in the beef during storage to possible production of organic acids. However in the present study, there was no significant difference $(\mathrm{p}<0.05)$ in the $\mathrm{pH}$ of the tsire samples stored in different packaging materials, probably because no starter culture was inoculated in any of the samples to stimulate production of organic acids that may bring about reduction in $\mathrm{pH}$.

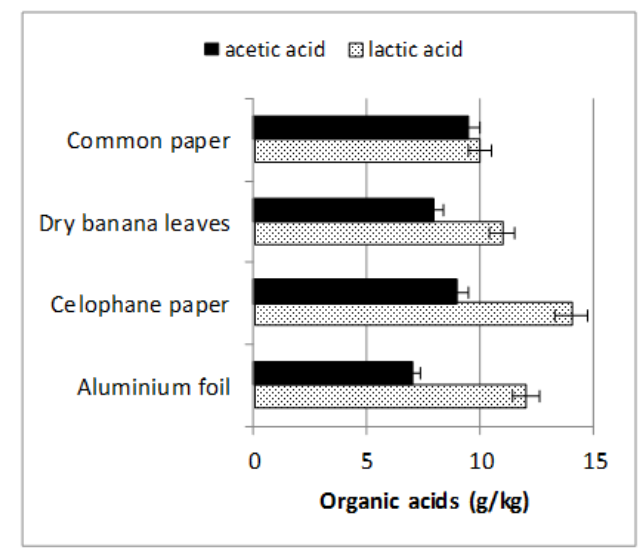

Figure 1. Measurement of organic acids (lactic and acetic acids) in the stick meat (tsire) samples wrapped in different packaging materials during spontaneous storage. 


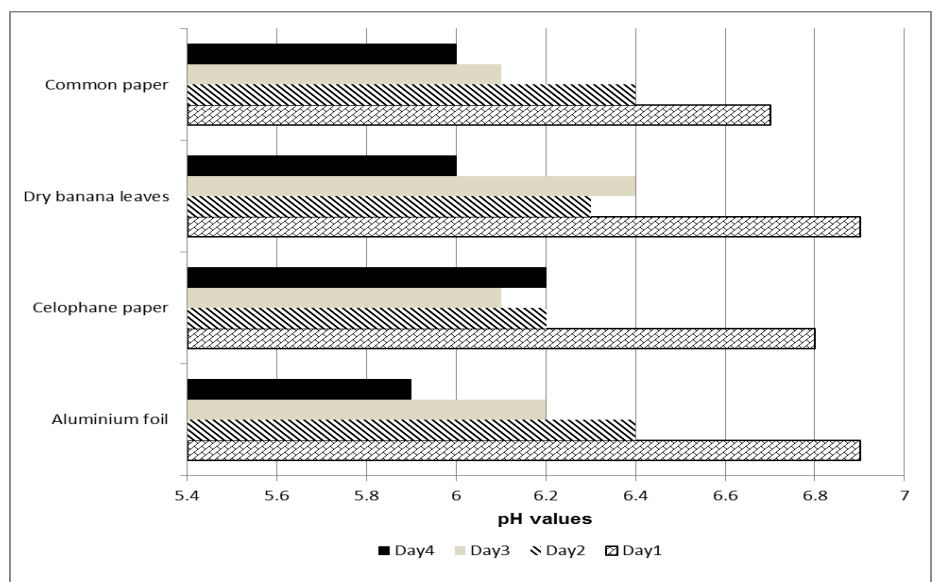

Figure 2. Measurement of $\mathrm{pH}$ values in the stick meat (tsire) samples wrapped in different packaging materials during spontaneous storage

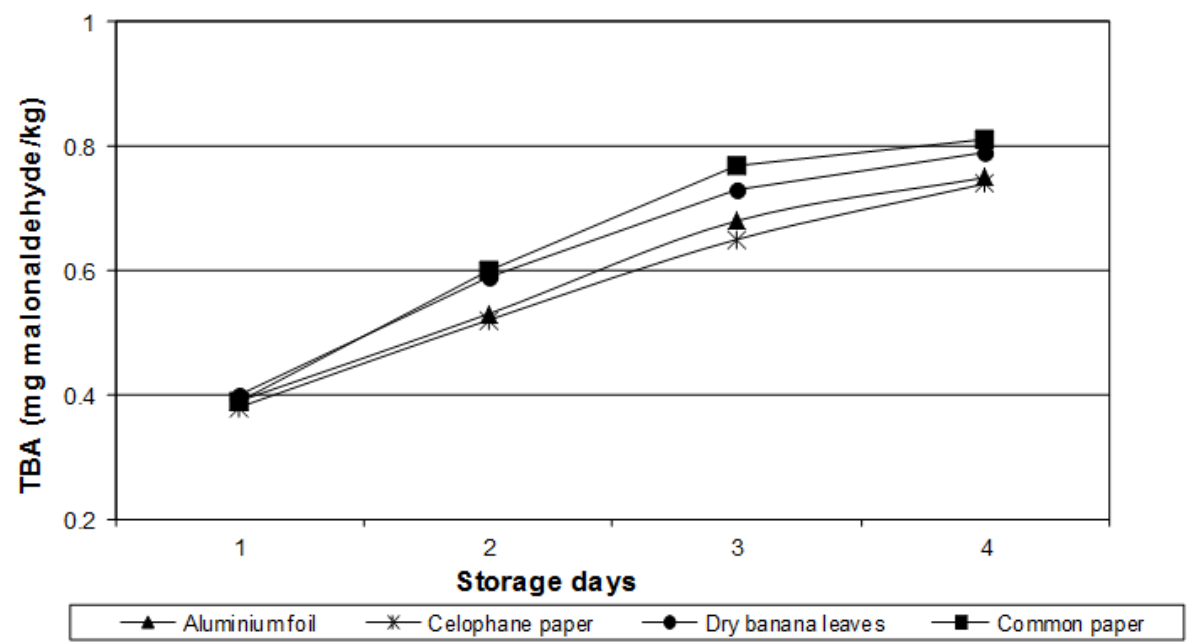

Figure 3. Thiobarbituric acids values of the stick meat (tsire) samples wrapped in different packaging materials during spontaneous storage.

The result of TBA analysis (mg malonaldehyde/kg; Figure 3) of tsire samples during storage showed that similar values $(\mathrm{p}>0.05)$ were recorded for the samples, irrespective of the packaging materials used. Increase in TBA value was observed in all the samples during storage, although values were higher in those stored in common paper throughout storage. TBA was comparatively lower in tsire stored in aluminium foil and cellophane paper, even though values were not significantly different $(\mathrm{p}>0.05)$ from those recorded for others. Olaoye [6] noted that TBA could be associated with rancidity development in food products through lipid oxidation, and increase in its value during storage may cause off flavour in meat products. The lower value of TBA recorded in the samples stored in aluminium foil and cellophane paper may be advantageous, as this may help prevent or reduce lipid oxidation in the meat product during storage, thereby reducing chances of spoilage. TBA values higher than 0.5 (mg malonaldehyde $/ \mathrm{kg}$ ) have been noted to trigger spoilage in meat during storage [14], and therefore all the different tsire samples in the present study are liable to spoilage during storage.

Some of the chemical volatiles identified in tsire samples were heptane, octane, 1,3-dimethyl-benzene, (e)-3-dodecene, 1,2-diepoxyhexadecane and himachala-2,4-diene (Table 1). Many of the volatiles were significantly different $(\mathrm{p}<0.05)$ in the different samples during stoare. Three aldehydes 3-methyl-butanal, nonanal and heptanal were identified in the meat product, having area units of greater than $1.0 \times 10^{4}$ AUs during the four day storage. It has been reported that presence of aldehydes such as heptanal and 
nonanal in relatively high concentration may indicate flavour deterioration which often result in development of rancid aroma in meat [15].

The principal component analysis (PCA) carried out on the volatiles of the tsire samples during storage (Figure 4) showed presence of certain compounds that have been reported as spoilage molecules of meat, including 3-methyl-1-butanol and 2-butanone [14,17]; this further indicates the liability of the meat product to spoilage during storage.



Figure 4. Principal component analysis of the volatiles using the SPME-GCMS peak area data from headspace of the stick meat product (tsire) during spontaneous storage. (Af, aluminium foil; Cp, cellophane paper; Dbl, dried banana leaves; Cop, common paper.)

Table 1. Area units $\left(\mathrm{x} 10^{4}\right)$ of chemical volatiles in the stick meat product (tsire) during spontaneous storage

\begin{tabular}{lccccccccccc}
\hline Compounds & RI & SD1 & StdD & SD2 & StdD & SD3 & StdD & SD4 & StdD & P-value & MI \\
\hline heptane & $<600$ & 31 & 6 & 35 & 7 & 39 & 9 & 51 & 3 & 0.003 & 1 \\
octane & $<600$ & 25 & 3 & 23 & 3 & 23 & 3 & 38 & 4 & 0.021 & 1 \\
1,3-dimethyl-Benzene & - & 26 & 12 & 43 & 19 & 76 & 21 & 129 & 42 & 0.018 & 2 \\
(e)-3-dodecene & 745 & 9 & 3 & 11 & 2 & 11 & 5 & 12 & 3 & 0.016 & 2 \\
1,2-diepoxyhexadecane & 827 & 58 & 8 & 48 & 11 & 40 & 9 & 46 & 10 & 0.004 & 2 \\
himachala-2,4-diene & 837 & 60 & 12 & 55 & 9 & 59 & 13 & 64 & 9 & 0.4271 & 1 \\
3-methyl-butanal & $<600$ & 1 & 0 & 1.5 & 1 & 15 & 5 & 56 & 7 & 0.001 & 2 \\
acetic-acid,-pentyl-ester & 656 & 102 & 12 & 167 & 10 & 182 & 45 & 177 & 59 & 0.034 & 2 \\
methyl-uronate & 698 & 3 & 1 & 8 & 2 & 10 & 3 & 25 & 5 & 0.009 & 2 \\
heptanal & 725 & 8 & 2 & 19 & 4 & 27 & 13 & 67 & 10 & 0.0008 & 1 \\
methyl-6-(2-furoyl) hexanoate & 821 & 13 & 6 & 38 & 12 & 40 & 6 & 52 & 11 & 0.0014 & 2 \\
methoxy-phenyl-oxime & 834 & 19 & 2 & 33 & 7 & 46 & 7 & 75 & 5 & 0.0002 & 2 \\
3-methyl-butanenitrile & 873 & 6 & 3 & 4 & 2 & 8 & 1 & 8 & 3 & 0.0007 & 2 \\
2,5-dimethyl-furan & 943 & 3 & 1 & 7 & 3 & 13 & 5 & 19 & 4 & 0.038 & 1 \\
2-pentyl-furan & 945 & 13 & 2 & 15 & 2 & 14 & 1 & 17 & 3 & 0.022 & 2 \\
nonanal & 982 & 7 & 1 & 15 & 4 & 21 & 80 & 31 & 12 & 0.0026 & 1 \\
\hline
\end{tabular}

Each value is mean of three replicates of samples; SD1, storage day 1; SD2, storage day 2; SD3, storage day 3; SD4, storage day 4; StdD, standard deviation; $P$-value, probability value; RI, retention 
index; MI, method of identification; 1, Identification using authentic standards; 2, Identification using retention indices from the literature and their mass spectra with the NIST mass spectral library

\section{Conclusions}

This study concluded that the use of different packaging materials in the storage of tsire may impart on production of organic acids in the product, and hence affect its shelf life and storage stability. It was further concluded that the possibility of spoilage being associated with the tsire samples during storage is very high, probably due to the spontaneous reactions of the miscellaneous microflora in the meat product. It is recommended that the use of biological agents, especially lactic acid bacteria (LAB) be adopted as biopreservatives during storage. This could promote secretion of organic substances, especially organic acids, capable of limiting spoilage through their action on spoilage organism.

\section{References}

1. A.A. Onilude, A.I. Sanni, O.A. Olaoye and S.T. Ogunbanwo. Influence of lactic cultures on the quality attributes of tsire, a West African stick meat. World Journal of Microbiology \& Biotechnology 2002. 18 pp. 615-619.

2. L. Ajala, T.A. Ibrahim and V.T. Adebote. Effect of different packaging materials on bacteriological quality of "Egidi". American Journal of Food and Nutrition 2011. 2 pp. 79-81.

3. N.O. Kabuo, L.O. Udeozor, N.C. Onuegbu, J.N. Nwosu, and M.U. Eme. Effect of Wrapping Materials on the Proximate Composition and Organoleptic Properties of Usu (Indigenous Meat Analogue) Produced from Big Mushroom (Lentinus Tuber-Regium) and Melon Seed (Colocynthis citrullus L). International Journal of Food and Nutrition Science 2013, 2(1) pp. 38-46.

4. O.O. Ogunsola and A.B. Omojola. Qualitative evaluation of Kilishi prepared from beef and pork. African Journal of Biotechnology 2008, 7(11), pp. 1753-1758.

5. O.A. Olaoye and C.E.R. Dodd. Evaluation of bacteriocinogenic Pediococcus acidilactici as protective culture in the preservation of tsire, a traditional Nigerian stick meat. Journal of Food Safety 2010. 30 pp. 867-888.

6. O.A. Olaoye. A preliminary study on the effect of storage period on flavour profile and consumers' acceptability of tsire, a Nigerian stick meat. AASCIT Journal of Chemistry 2015. 2 pp. 77-84.

7. O.A. Olaoye, A.A. Onilude, A.A. and C.E.R. Dodd. Identification of Pediococcus spp. from beef and evaluation of their lactic acid production in varying concentrations of different carbon sources. Advances in Natural and Applied Sciences 2006. 2 pp. 197-207.

8. O.A. Olaoye and A.A. Onilude. Investigation on the potential use of biological agents in the extension of fresh beef in Nigeria. World Journal of Microbiology and Biotechnology 2010. 26 pp. 1445-1454.

9. O.A. Olaoye. A preliminary study on the effect of storage period on flavour profile and consumers' acceptability of tsire, a Nigerian stick meat. AASCIT Journal of Chemistry 2015, 2(3) pp. 77-84.

10.C. Liu, J. Zhang, Z. Zhou, Z. Hua, H. Wan, Y. Xie, Z. Wang and L. Deng. analysis of volatile compounds and identification of characteristic aroma components of Toona sinensis (A. Juss.) Roem. using GC-MS and GC-O. Food Nutritional Sciences 2013. 4 pp. 305-314.

11.H.H.M. Fadel, A.A. Samad, M.I. Kobeasy, M.A. Mageed and S.N. Lotfy. Flavour quality and stability of an encapsulated meat-like process flavouring prepared from soybean based acid hydrolyzed protein. International Journal of Food Processing and Technology 2015. 2 pp. 17-25.

12.O.A. Olaoye and A.A. Onilude. Quantitative estimation of antimicrobials produced by Lactic Acid Bacteria isolated from Nigerian beef bacteria. International Food Research Journal 2011. 18 pp. 1104-1110.

13.O.A. Olaoye. Characteristics of lactic acid bacteria being proposed as starter cultures for extending the shelf life of a Nigerian grilled meat product tsire. Asian Journal of Science and Technology 2014. 5(11) pp. 639-643.

14.K.I. Sallama and K. Samejima. Microbiological and chemical quality of ground beef treated with sodium lactate and sodium chloride during refrigerated storage. Lebenson Wiss Technology 2004. 37 pp. 865-871.

15.G. Kaban. Changes in the composition of volatile compounds and in microbiological and physicochemical parameters during pastırma processing. Meat Science 2009. 82 pp. 17-23.

16.M. Estevez, S. Ventanas and R. Cava. Protein oxidation in frankfurters with increasing levels of added rosemary essential oil: effect on colour and texture deterioration. Journal of Food Science 2005. 70 pp. 427-432. 
17.A. Casaburi, A. Nasi, I. Ferrocino, R. DI Monaco, G. Mauriello, F. Villani and D. Ercolini. Spoilage-related activity of Carnobacterium maltaromaticum strains in air-stored and vacuum-packed meat. Applied and Environmental Microbiology 2011. 7 pp. 7382-7393. 